Supplement of Clim. Past, 17, 241-252, 2021

https://doi.org/10.5194/cp-17-241-2021-supplement

(c) Author(s) 2021. This work is distributed under

the Creative Commons Attribution 4.0 License.

(c) (i)

Supplement of

\title{
The response of annual minimum temperature on the eastern central Tibetan Plateau to large volcanic eruptions over the period 1380-2014 CE
}

Yajun Wang et al.

Correspondence to: Yong Zhang (zhangyong@igsnrr.ac.cn)

The copyright of individual parts of the supplement might differ from the CC BY 4.0 License. 
Correlation coefficients were calculated to better understand the representativeness of the climate data recorded by six proximate meteorological stations (DR, XH, HN, JZ, MQ, and HZ) (Tables S1 and S2).

Table S1. Correlation coefficients for total annual precipitation and annual $\mathrm{T}_{\text {mean }}$.

\begin{tabular}{|c|c|c|c|c|c|c|}
\hline & DR & $\mathrm{XH}$ & $\mathrm{HN}$ & $\mathrm{JZ}$ & MQ & $\mathrm{HZ}$ \\
\hline DR & - & $\begin{array}{l}0.351 * * \\
(55)\end{array}$ & $\begin{array}{l}0.495 * * \\
(56)\end{array}$ & $\begin{array}{l}0.396 * * \\
(57)\end{array}$ & $\begin{array}{l}0.519 * * \\
(49)\end{array}$ & $\begin{array}{l}0.174 \\
(58)\end{array}$ \\
\hline $\mathrm{XH}$ & $\begin{array}{l}0.781 * * \\
(55)\end{array}$ & - & $\begin{array}{l}0.438 * * \\
(55)\end{array}$ & $\begin{array}{l}0.323^{*} \\
(55)\end{array}$ & $\begin{array}{l}0.333^{*} \\
(49)\end{array}$ & $\begin{array}{l}0.257 \\
(55)\end{array}$ \\
\hline $\mathrm{HN}$ & $\begin{array}{l}0.164 \\
(56)\end{array}$ & $\begin{array}{l}0.021 \\
(55)\end{array}$ & - & $\begin{array}{l}0.588 * * \\
(56)\end{array}$ & $\begin{array}{l}0.683 * * \\
(49)\end{array}$ & $\begin{array}{l}0.506 * * \\
(56)\end{array}$ \\
\hline $\mathrm{JZ}$ & $\begin{array}{l}0.935^{* *} \\
(57)\end{array}$ & $\begin{array}{l}0.849 * * \\
(55)\end{array}$ & $\begin{array}{l}0.026 \\
(56)\end{array}$ & - & $\begin{array}{l}0.763 * * \\
(49)\end{array}$ & $\begin{array}{l}0.555 * * \\
(57)\end{array}$ \\
\hline MQ & $\begin{array}{l}0.911^{* *} \\
(49)\end{array}$ & $\begin{array}{l}0.863 * * \\
(49)\end{array}$ & $\begin{array}{l}0.214 \\
(49)\end{array}$ & $\begin{array}{l}0.953 * * \\
(49)\end{array}$ & - & $\begin{array}{l}0.608 * * \\
(49)\end{array}$ \\
\hline $\mathrm{HZ}$ & $\begin{array}{l}0.772 * * \\
(58)\end{array}$ & $\begin{array}{l}0.893 * * \\
(55)\end{array}$ & $\begin{array}{l}0.004 \\
(56)\end{array}$ & $\begin{array}{l}0.867 * * \\
(57)\end{array}$ & $\begin{array}{l}0.906 * * \\
(49)\end{array}$ & - \\
\hline
\end{tabular}

Note: DR: Dari; XH: Xinghai; HN: Henan; JZ: Jiuzhi; MQ: Maqu; HZ: Hezuo

$* * 0.01$ significance level; $* 0.05$ significance level. The number years common to all six datasets are shown in brackets.

Correlation coefficients in upper right are for total annual precipitation.

Correlation coefficients in lower left are for annual $\mathrm{T}_{\text {mean. }}$.

Table S2. Correlation coefficients for the annual $\mathrm{T}_{\max }$ and $\mathrm{T}_{\min }$ recorded at the meteorological stations.

\begin{tabular}{|c|c|c|c|c|c|c|}
\hline & DR & $\mathrm{XH}$ & $\mathrm{HN}$ & $\mathrm{JZ}$ & MQ & $\mathrm{HZ}$ \\
\hline DR & - & $\begin{array}{l}0.789 * * \\
(55)\end{array}$ & $\begin{array}{l}0.458 * * \\
(56)\end{array}$ & $\begin{array}{l}0.755 * * \\
(57)\end{array}$ & $\begin{array}{l}0.900 * * \\
(49)\end{array}$ & $\begin{array}{l}0.715 * * \\
(58)\end{array}$ \\
\hline XH & $\begin{array}{l}0.816^{* *} \\
(55)\end{array}$ & - & $\begin{array}{l}0.576 * * \\
(55)\end{array}$ & $\begin{array}{l}0.789 * * \\
(55)\end{array}$ & $\begin{array}{l}0.923 * * \\
(49)\end{array}$ & $\begin{array}{l}0.936^{* *} \\
(55)\end{array}$ \\
\hline $\mathrm{HN}$ & $\begin{array}{l}0.08 \\
(56)\end{array}$ & $\begin{array}{l}-0.212 \\
(55)\end{array}$ & - & $\begin{array}{l}0.522 * * \\
(56)\end{array}$ & $\begin{array}{l}0.643 * * \\
(49)\end{array}$ & $\begin{array}{l}0.398 * * \\
(56)\end{array}$ \\
\hline $\mathrm{JZ}$ & $\begin{array}{l}0.927 * * \\
(57)\end{array}$ & $\begin{array}{l}0.813 * * \\
(55)\end{array}$ & $\begin{array}{l}-0.032 \\
(56)\end{array}$ & - & $\begin{array}{l}0.833 * * \\
(49)\end{array}$ & $\begin{array}{l}0.738 * * \\
(57)\end{array}$ \\
\hline MQ & $\begin{array}{l}0.848 * * \\
(49)\end{array}$ & $\begin{array}{l}0.730 * * \\
(49)\end{array}$ & $\begin{array}{l}-0.035 \\
(49)\end{array}$ & $\begin{array}{l}0.926 * * \\
(49)\end{array}$ & - & $\begin{array}{l}0.875 * * \\
(49)\end{array}$ \\
\hline $\mathrm{HZ}$ & $\begin{array}{l}0.792 * * \\
(58)\end{array}$ & $\begin{array}{l}0.787 * * \\
(55)\end{array}$ & $\begin{array}{l}-0.092 \\
(56)\end{array}$ & $\begin{array}{l}0.848 * * \\
(57)\end{array}$ & $\begin{array}{l}0.899 * * \\
(49)\end{array}$ & - \\
\hline
\end{tabular}

Note: DR: Dari; XH: Xinghai; HN: Henan; JZ: Jiuzhi; MQ: Maqu; HZ: Hezuo

$* * 0.01$ significance level; $* 0.05$ significance level. The number years common to all six 
datasets are shown in brackets. Correlation coefficients in the upper right are for annual $\mathrm{T}_{\max }$. Correlation coefficients in the lower left are for annual $\mathrm{T}_{\text {min. }}$.

The significant positive correlations for precipitation and temperature recorded at the six stations indicate that these data are representative of the regional climate. The $T_{\text {mean }}$ and $T_{\min }$ data from station $\mathrm{HN}$ does not correlate significantly with the data of other stations. It is notable that the $\mathrm{HN} \mathrm{T}_{\min }$ is even negatively correlated with data from four of the other five stations (Table S2).

Station HN, which has a relatively long observation interval (1960-2015), is located $\sim 60 \mathrm{~km}$ from the sampling site, closer than any of the others. Its poor correlation with the other stations was therefore examined further. Jiuzhi station, which has the highest correlation with the other stations, was chosen for comparison (Figure S1). Temperatures decreased abruptly at HN station in 1981, especially annual $\mathrm{T}_{\text {mean }}$ and annual $\mathrm{T}_{\min }$. This was an instrumental error, therefore, we then made the correction. The differences in temperature between the $\mathrm{JZ}$ and HN stations over the period was added to the HN station data for the years following 1981. As a result, the correlation coefficients of the original and corrected temperatures, in particular the annual $\mathrm{T}_{\text {mean }}$ and $\mathrm{T}_{\min }$ values (Table $\mathrm{S} 3$ ), increased to the 0.01 significance level. The corrected values were chosen for the following study.
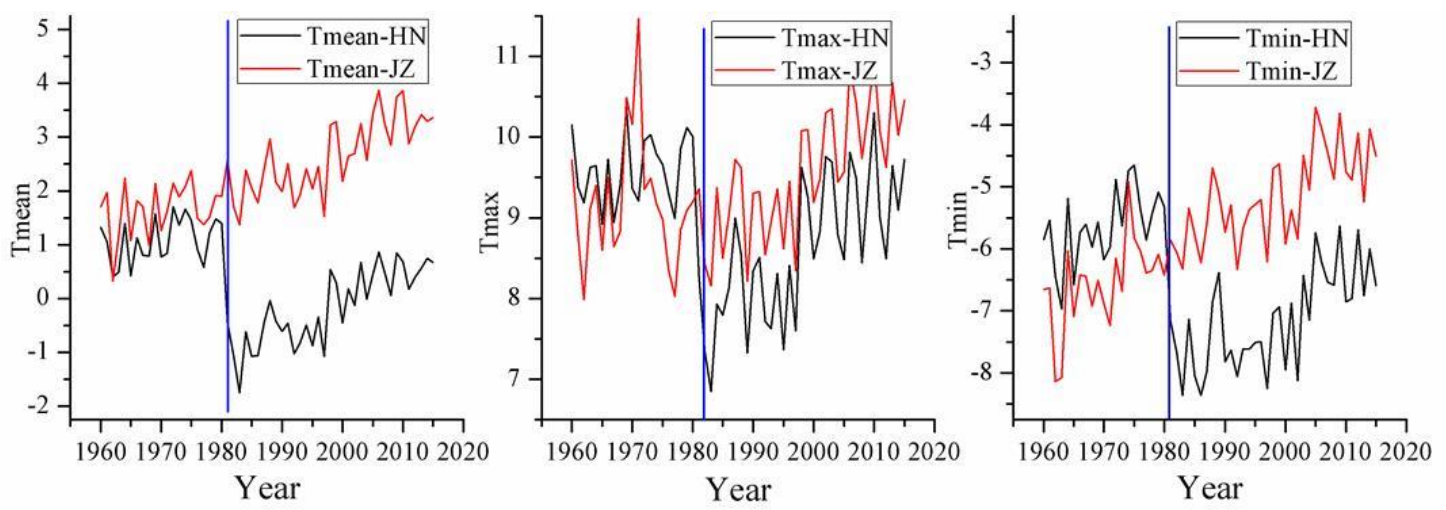

Figure S1. Changes in annual temperatures at the HN and JZ stations. HN: Henan; JZ: Jiuzhi. 
Table S3. Correlations between the original and corrected annual HN station temperatures and those of other stations.

\begin{tabular}{llllll}
\hline & $\mathrm{DR}$ & $\mathrm{XH}$ & $\mathrm{JZ}$ & $\mathrm{MQ}$ & $\mathrm{HZ}$ \\
\hline Original $\mathrm{T}_{\text {mean }}$ & 0.164 & 0.021 & 0.026 & 0.214 & 0.004 \\
\hline Corrected $\mathrm{T}_{\text {mean }}$ & $0.802^{* *}$ & $0.681^{* *}$ & $0.748^{* *}$ & $0.812^{* *}$ & $0.686^{* *}$ \\
\hline Original $\mathrm{T}_{\max }$ & $0.458^{* *}$ & $0.576^{* *}$ & $0.522^{* *}$ & $0.643 * *$ & $0.398^{* *}$ \\
\hline Corrected $_{\max }$ & $0.797^{* *}$ & $0.874^{* *}$ & $0.761^{* *}$ & $0.898^{* *}$ & $0.764 * *$ \\
\hline Original $\mathrm{T}_{\min }$ & 0.08 & -0.212 & -0.032 & -0.035 & -0.092 \\
\hline Corrected $\mathrm{T}_{\min }$ & $0.871^{* *}$ & $0.648^{* *}$ & $0.843^{* *}$ & $0.773^{* *}$ & $0.745^{* *}$ \\
\hline
\end{tabular}

Note: Dari: DR; XH: Xinghai; JZ: Jiuzhi; MQ: Maqu; HZ: Hezuo; **=0.01 significance level

In addition, the interpolation approach was used to estimate the missing values for April and May 1962 at the JZ station, and for January $1960 \mathrm{~T}_{\max }$ at the $\mathrm{XH}$ station. The procedure is described below.

Meteorological stations with complete data records in Qinghai, Gansu, and Sichuan Provinces were selected, and stepwise regression was used to interpolate the missing data for $\mathrm{JZ}$ and $\mathrm{XH}$. The results are shown in Table S4.

Table S4. Interpolated values for missing climate data.

\begin{tabular}{ccccccccccc}
\hline Station & Year & Month & $\begin{array}{l}\text { Climate } \\
\text { factor }\end{array}$ & $\begin{array}{l}\text { Station } \\
\text { number }\end{array}$ & $\begin{array}{l}\text { Selected } \\
\text { station }\end{array}$ & $\begin{array}{l}\text { Interpolated } \\
\text { value }\end{array}$ & $\mathrm{R}$ & $\mathrm{R}^{2}$ & $\mathrm{R}_{\text {adj }}^{2}$ \\
\hline $\mathrm{JZ}$ & 1962 & April & $\mathrm{P}$ & 83 & 4 & $37.8 \mathrm{~mm}$ & 0.792 & 0.627 & 0.598 \\
\hline $\mathrm{JZ}$ & 1962 & April & $\mathrm{T}_{\text {mean }}$ & 83 & 3 & $1.6^{\circ} \mathrm{C}$ & 0.976 & 0.952 & 0.949 \\
\hline $\mathrm{JZ}$ & 1962 & April & $\mathrm{T}_{\max }$ & 81 & 3 & $11.4^{\circ} \mathrm{C}$ & 0.911 & 0.831 & 0.821 \\
\hline $\mathrm{JZ}$ & 1962 & April & $\mathrm{T}_{\min }$ & 82 & 3 & $-5.4^{\circ} \mathrm{C}$ & 0.893 & 0.798 & 0.786 \\
\hline $\mathrm{JZ}$ & 1962 & May & $\mathrm{P}$ & 78 & 5 & $71.7 \mathrm{~mm}$ & 0.789 & 0.623 & 0.584 \\
\hline $\mathrm{JZ}$ & 1962 & May & $\mathrm{T}_{\operatorname{mean}}$ & 79 & 6 & $4.0^{\circ} \mathrm{C}$ & 0.982 & 0.965 & 0.961 \\
\hline $\mathrm{JZ}$ & 1962 & May & $\mathrm{T}_{\max }$ & 79 & 3 & $11.3^{\circ} \mathrm{C}$ & 0.879 & 0.773 & 0.760 \\
\hline $\mathrm{JZ}$ & 1962 & May & $\mathrm{T}_{\min }$ & 80 & 2 & $-1.1^{\circ} \mathrm{C}$ & 0.954 & 0.911 & 0.907 \\
\hline $\mathrm{XH}$ & 1960 & January & $\mathrm{T}_{\max }$ & 82 & 14 & $-1.7^{\circ} \mathrm{C}$ & 0.993 & 0.987 & 0.982 \\
\hline
\end{tabular}


Note: JZ: Jiuzhi; XH: Xinghai; $* \mathrm{R}^{2}{ }_{\text {adj }}=$ adjusted $\mathrm{R}^{2}$ 